\title{
The perception of ICT skills and challenges of usage of technologies among the library professionals of the Gujarat State during the COVID 19: a comprehensive study
}

\author{
Devashri K. Shastri ${ }^{1}$ (D) $\cdot$ Pradipsinh Chudasma $^{2}$ (D)
}

Accepted: 12 May 2021 / Published online: 25 May 2021

(c) The Author(s), under exclusive licence to Springer Nature B.V. 2021

\begin{abstract}
It is witnessed that the role of technology became crucial, and people are dependent on technologies to continue creative, professional, and academic activities during a pandemic situation when most of the libraries were not accessible physically worldwide. This study aims to know the level of ICT skills, competencies, usage of technologies, challenges, and services offered by library professionals of Gujarat state, India during the lockdown period. Due to the emergence of advanced technologies, the omnipresence of the internet, the explosive growth of e-resource, and pandemic situation, it is imperative for library professionals to acquire new ICT skills, techniques and apply them to disseminate information and reach out to library patrons. This study reveals how library professionals provided services and resources to users when they need resources/ information and which techniques/ methods library professionals adopted to fulfill the requirements of patrons during COVID19. The methods adopted by patrons to access library resources were also studied. The 100 questionnaires were circulated via social media and email to library professionals of Gujarat state and 77 (77\%) responses received in this study.
\end{abstract}

Keywords ICT skills · Technologies · Library services · Lockdown · COVID-19 · Challenges · LIS professionals · Attitude of LIS professionals

Pradipsinh Chudasma

pradipchudasma@gmail.com

Devashri K. Shastri

shastri.devashri@gmail.com

1 Department of Library and Information Science, Gujarat University, Navrangpura, Ahmedabad, Gujarat 380009, India

2 Institute of Technology, Nirma University, S. G. Highway, Ahmedabad, Gujarat 382481, India 


\section{Introduction}

The COVID-19 situation brought drastic changes in the educational scenario worldwide. However, the teaching-learning process continues and it is witnessed that the role of technologies increased unpredictably. To take the advantages of 'ubiquitous' technologies during the pandemic situation, the library professionals and patrons should update themselves as per technological innovations. According to the second law of library and information science by Dr. S. R. Ranganathan "Every reader his/her book" (Sen, 2008), in current COVID-19 pandemic situation users are not able to access the library physically so the library has to reach to users to fulfill their requirements via different platforms and technologies like library website, online Institute repository, FAQ, Library Mobile App, Remote login services, WhatsApp group, Online databases, etc. To form an information literate society, librarians and information science professionals must possess ICT (Information and Communication Technology) skills/ competencies, critical thinking ability, information skills, information seeking, media literacy, communication skills, and community participation. The terms IT and ICT are used interchangeably, Buarki, Hepworth, and Murray (2011) defined ICT skills as the skills needed to "access, evaluate, communicate information, and to produce documents electronically by the use of computers and communication technologies'.

IT (Information Technology) is referred to as acquiring, processing, storing, and disseminating information via the medium of computer systems and telecommunication devices, while ICT is a lengthened synonym of IT, focusing more upon telecommunication, wireless and audio-visual systems. ICT is an integrated part of libraries before COVID 19, however, its role extended in the present scenario. The study about information needs of faculties of the university in the ICT environment described that $80 \%$ of respondents considered ICT as useful while $13 \%$ considered ICT as stressful, moreover the accuracy and quality of information was faculty's major concern while using web resources (Jankowska, 2004).

Another study described the skill requirements of the digital academic library scenario are disciplinary Knowledge, generic (transferrable) skills, personal competencies such as perpetual learning, the capacity to work independently, flexibility, fostering change, etc., and more demand for technological skills (Raju, 2014). This study investigated the ICT skills of LIS professionals, usage, and challenges related to the application of ICT and the role of ICT to serve the user community.

Palczyńska \& Rynko (2020) observed ICT skills measurement in the social surveys by using logistic regression models. The study described "those individuals who are most likely to possess ICT skills are most likely to over report having these skills. The propensity to over report decreases with age and increases with years of education and numeracy level; women are less likely than men to overestimate their skills." The findings of the study reported social desirability plays key role in forming answers to questions about ICT skills while no major role of information deficits was found in the skills reporting process. This study emphasizes measuring ICT skills of LIS professionals of Gujarat along with challenges associated with the usage of ICT.

\section{Literature review}

The most pertinent studies which have been reviewed by the researchers have been presented into the following subsections: 


\subsection{ICT Skills/ competencies of LIS professionals}

Ahmad et al. (2020) investigated the usage and impact of ICT among library professionals of government degree colleges of Kashmir state, India. The study reveals the significant role of ICT to handle libraries and to provide fast and accurate library services to patrons. The use of OPAC, library automation SOUL software, and Barcode technology played a key role to transform libraries, library professionals realized the need for training at regular intervals to work efficiently in the digital age.

Babu et al. (2007) studied the ICT skills of librarians working in the engineering educational institution of Tamilnadu, India, and data collected to study the theme via a structured questionnaire from 171 library professionals. The findings of the study reported that there is a need to focus more upon skills about services of digital library and network-based library services, also given several suggestions to enhance ICT skills among library professionals.

Basahuwa et al. (2020) examined the job performance of librarians and the influence of ICT skills in public universities of North-Central Nigeria. The findings of the study reported that the library professionals' basic and professional ICT skills are high and they use them to provide efficient library services.

Gurikar and Mukherjee (2015) studied the usage of IT in the academic libraries of higher education in Chattisgarh, India. The six academic libraries responded and library infrastructure, facilities, services, collection development policies and issues, the status of library automation, ICT usage, etc. studied.

Oyedokun et al. (2018) evaluated the ICT competencies of LIS professionals working in the universities of Kwara state, Nigeria, the study analyzed 191 responses. The study differentiated three types of ICT skills: Lower level, intermediate, and high-level skills. The study concluded with suggestions about redesigning LIS curriculum, allocation of adequate funds to improve information infrastructure, and to train LIS professionals, the staff with high-level skills should share their knowledge with colleagues, and organize seminars/ workshops at regular intervals.

Seena and Pillai (2014) investigated ICT skills of LIS professionals employed in the Kerala University, India comprehensively. They studied ICT skills to handle resources, awareness about library automation and digital library software, LIS professional's attitude towards ICT, etc. The need to improve IT infrastructure and regular training of library professionals are required to utilize library e-resources effectively.

\subsection{Information literacy skills}

Thanuskodi (2019) defined information literacy and its need in the Indian LIS scenario. The study explored information literacy skills among LIS professionals, 572 questionnaires were analyzed to collect data about the information literacy skills of library professionals. To promote information literacy, collaboration between librarians and the teaching staff is required, the LIS professionals should teach skills regarding how to identify relevant information from authenticate sources, evaluate and utilize information to especially PG students and research scholars. 


\subsection{Role of librarians}

Kaur and Sharma (2018) reviewed the need for ICT in the library, the aims of technological literacy, description of job titles that LIS professionals have given, and explained factors that have changed the role of librarians. The authors identified various ICT skills/competencies that are relevant in the digital library, as well as dynamic service scenarios, and the sources to develop skills, which are explained comprehensively in the study.

Mandal and Dasgupta (2018) recognizes that the present librarianship demands technical and scholarly knowledge besides core traditional librarianship skills. The librarians need to update themselves continuously, the study also observed that young librarians are usually expert in handling technologies and update themselves as per innovation. The study suggests that library professionals should participate in professional development activities.

Jalal (2019) explained the changing role of librarians as a manager, leader, resource person, inspired educator, and master of the web technologies in the digital world. They have described various skills that are essential for LIS professionals such as managerial skills, information retrieval, technological, communication, negotiation, resource organization, discovery services, use of OSS (Open Source Software) to manage information resources and provide effective library services, international research collaboration, and forecasting skills about the collection, etc.

\section{Objectives}

Objectives of the present study are as follows:

1. To explore levels of ICT skills/ competencies possessed by the library and information professionals.

2. To examine the role of technologies to disseminate information and to provide library and information services.

3. To identify barriers/challenges about the application of ICT in the library scenario.

4. To recommend measures for the improvement of ICT skill development among library professionals and about improving library service scenario.

\section{Scope and limitation of the study}

This study is based upon the survey research method of 77 library professionals working in the higher education institutions of the Gujarat State, India. However, there are more than 200 well established higher academic institutes and approximately 450 library and information professionals working in the Gujarat State. The role of ICT has increased significantly especially, during the pandemic situation; there are multiple aspects and purposes to utilize technologies in the library scenario. This study examines the role of ICT in acquiring information and dissemination of the information mainly. 


\section{Research methodology}

The structured questionnaire is used to collect the relevant data from the library professionals working in the government, centrally funded, granted, autonomous/ self-financed academic colleges and universities of the Gujarat state, India. The questionnaire contains short descriptive, multiple-choice and statement type questions, the unidimensional and psychometric rating Scale-Likert five-point scale is used to study the attitude of library professionals towards the application of ICT. The 100 questionnaires were circulated among library professionals via email, and social media, 77 (77\%) responses are received. MS Excel is used to analyze collected data.

\section{Finding and discussion}

The information about the type of academic institutes/ colleges/ Universities of respondents is analyzed and presented in Table 1. The majority of respondents i.e. $39(50.70 \%)$ are working in the autonomous/ self-financed institutes and 32 (42\%) respondents are working in government institutions; the total response was collected from 77 library professionals working in the four different categories of academic organization of the Gujarat State. The courses offered at the institutes of respondents are Under Graduate, Post Graduate, Diploma, M. Phil. and Ph. D.

\subsection{Basic Information of respondents}

In Table 2 the information of designation, basic qualification, and professional qualification of respondents are combined and presented. The designation of the majority of respondents is librarian i.e. $49(63.7 \%)$ and 11 (14.3\%) respondents are assistant librarians. The $35.1 \%$ of library professionals' basic qualification is BCom. While the total of $23.4 \%$ of respondents studied MA and MCom and 8 respondents' basic qualification is BCA, MCA, mentioned in other categories. About the professional qualification, $84.4 \%$ of respondents have MLISc degree, $48.1 \%$ of respondents passed UGC NET/ GSLET examination, while $18.2 \%$ of respondents are $\mathrm{Ph}$. D. degree holders.

\subsection{Year of establishment of institutes/ colleges/ university:}

From the above Figure 1, we can analyze that before 1950, 3 (3.90\%) institutions have established, while 7 (9.10\%) institutions have established during the year $1951-1970$.

Table 1 Type of the Academic Institutes/College/University

\begin{tabular}{llll}
\hline Sr. no. & $\begin{array}{l}\text { Type of academic institutes/ } \\
\text { college/university }\end{array}$ & Respondents & Percentage \\
\hline 1 & Autonomous/self finance & 39 & $50.70 \%$ \\
2 & Government & 32 & $42.00 \%$ \\
3 & Grant in aid & 5 & $6.00 \%$ \\
4 & Central government & 1 & $1.30 \%$ \\
& Total & 77 & 100 \\
\hline
\end{tabular}


Table 2 Designation, basic qualification and professional qualification of respondents

\begin{tabular}{|c|c|c|c|c|c|c|c|c|}
\hline \multicolumn{3}{|l|}{ Designation } & \multicolumn{3}{|c|}{ Basic qualification } & \multicolumn{3}{|c|}{ Professional qualification } \\
\hline Post & \multicolumn{2}{|c|}{$\begin{array}{l}\text { No. of } \\
\text { respondents }\end{array}$} & Degree & \multicolumn{2}{|c|}{$\begin{array}{l}\text { No. of } \\
\text { respondents }\end{array}$} & Degree & \multicolumn{2}{|c|}{$\begin{array}{l}\text { No. of } \\
\text { respond- } \\
\text { ents and } \\
\text { percent- } \\
\text { age }\end{array}$} \\
\hline Library/ technical assistant & 8 & $10.4 \%$ & BCom & 27 & $35.1 \%$ & MLISc & 65 & $84.4 \%$ \\
\hline Library professional & 7 & $9.0 \%$ & $\mathrm{BA}$ & 17 & $22.0 \%$ & BLISc & 19 & $24.7 \%$ \\
\hline Assistant librarian & 11 & $14.3 \%$ & MA & 9 & $11.7 \%$ & $\mathrm{PhD}$ & 14 & $18.2 \%$ \\
\hline Deputy librarian & 2 & $2.6 \%$ & MCom & 9 & $11.7 \%$ & MPhil & 11 & $14.3 \%$ \\
\hline Librarian & 49 & $63.7 \%$ & $\mathrm{BSc}$ & 5 & $6.6 \%$ & UGC NET/ SLET & 37 & $48.1 \%$ \\
\hline Total & 77 & 100 & MSc & 2 & $2.6 \%$ & & & \\
\hline & & & Other & 8 & $10.3 \%$ & & & \\
\hline
\end{tabular}

Multiple options selected by respondents

\section{Year of Establishment of Institutes/ Colleges/ University:}



Fig. 1 Year of Establishment of Institutes/Colleges/University

During 1971 - 1990, 5 (6.50\%), from 1991 to 2010, 40 (51.90\%) which is the highest, and $22(28.60 \%)$ academic institutes came into existence after 2010.

\subsection{Library facilities}

The information about basic library facilities is mentioned in Table 3. The seven libraries are having other facilities such as LCD, Projector and RFID. 
Table 3 Library facilities

\begin{tabular}{llll}
\hline Sr. no. & Library facility & Respondents & Percentage (\%) \\
\hline 1 & Reading Room & 72 & 93 \\
2 & Internet & 66 & 85.71 \\
3 & Library Building & 56 & 72.72 \\
4 & Photocopying & 51 & 66.23 \\
5 & Scanning & 45 & 58.44 \\
6 & Printing & 44 & 57.14 \\
7 & Other & 7 & 9.09 \\
\hline
\end{tabular}

Multiple options selected by respondents

Table 4 Library and information services

\begin{tabular}{lllc}
\hline Sr. no. & Library and information services services & Respondents & Percentage (\%) \\
\hline 1 & Circulation & 77 & 100.00 \\
2 & New arrivals & 74 & 96.1 \\
3 & Reference service & 73 & 94.8 \\
4 & Documents delivery services (DDS) & 53 & 68.8 \\
5 & Newspapers clippings & 62 & 80.5 \\
6 & Online database search & 61 & 79.2 \\
7 & CAS (current awareness service) & 54 & 70.1 \\
8 & SDI (selective dissemination of information) & 44 & 57.1 \\
9 & ILL (inter library loan) & 42 & 54.5 \\
10 & Value added services & 39 & 50.6 \\
11 & Indexing and abstracting service & 19 & 24.7 \\
12 & Other & 6 & 7.79 \\
\hline
\end{tabular}

Multiple options selected by respondents

\subsection{Library and information services}

Table 4 describes the library and information services offered by the library professionals. The value-added services include informing patrons about upcoming conferences/workshops/webinars/seminars, job opportunities, and competitive exams related information. The six respondents are offering other services such as Institutional Repository (IR) and plagiarism checking software-based service. However, during COVID 19, most of these services discontinued though demanded via social media and emails, while internet-based and online services were continued.

\subsection{Details of library staff}

Table 5 exhibits the details of library staff, 36 respondents (46.7\%) have 2 to 5 library staff, $41.6 \%$ of respondents have only one full-time librarian working in the library, $6(7.8 \%)$ respondents have more than one departmental library on the campus and have more than 10 library staff members. 
Table 5 Total number of library staff

Table 6 Total number of books (print)

Table 7 Details of total number of print journals, periodicals, magazines subscribed by library

\begin{tabular}{llll}
\hline Sr. no. & No. of library staff & Respondents & Percentage (\%) \\
\hline 1 & 0 to 1 & 32 & 41.6 \\
2 & 2 to 5 & 36 & 46.7 \\
3 & 6 to 10 & 3 & 3.9 \\
4 & More than 10 & 6 & 7.8 \\
& Total & 77 & 100 \\
\hline
\end{tabular}

\begin{tabular}{llll}
\hline Sr. no. & No. of books & Respondents & Percentage \\
\hline 1 & $1-2,000$ & 2 & 2.60 \\
2 & $2,001-5,000$ & 14 & 18.18 \\
3 & $5,001-10,000$ & 28 & 36.37 \\
4 & $10,001-15,000$ & 5 & 6.50 \\
5 & $15,001-20,000$ & 6 & 7.79 \\
6 & $20,001-30,000$ & 4 & 5.19 \\
7 & $30,001-50,000$ & 5 & 6.49 \\
8 & More than 50,000 & 13 & 16.88 \\
Total & & 77 & 100 \\
\hline
\end{tabular}

\begin{tabular}{llll}
\hline Sr. no. & $\begin{array}{l}\text { No. of print journals/ } \\
\text { magazines subscribed }\end{array}$ & Respondents & Percentage \\
\hline 1 & 1 to 20 & 27 & 35.1 \\
2 & 21 to 30 & 15 & 19.4 \\
3 & 31 to 50 & 11 & 14.3 \\
4 & More than 50 & 24 & 31.2 \\
& Total & 77 & 100
\end{tabular}

\subsection{Information about the library resources}

From Table 6, it is observed that 28 (36.37\%) academic libraries of respondents have library collection consists of 5001 to 10,000 books. While from Table 7, observed $27(35.1 \%)$ respondents of institutions subscribe to less than 20 journals/periodicals (print) annually.

In India, e-Resources are subscribed via library consortia or directly. Broadly consortia models are classified into five categories: Centrally funded, Open, Closed, National, and Shared budget models. In this study, all institutes subscribe to e-resources via consortia such as CeRA, DELNET, eShodhSindhu (merging three consortia- INDEST-AICTE, NLIST, and UGC INFONET), IIMs library consortia, etc. The libraries subscribed databases such as ACM, ASCE, ASME, EBSCO, Elsevier, IEEE, NPTEL, SCOPUS, etc. and also open access resources such as DOAB, DOAJ, NDL, PLOS, Shodhganga, SWAYAM are used.

INFLIBNET's NLIST is subscribed by 32 respondents working in government colleges mainly. The college administrator creates a valid user ID and password, users can access e-resources of NLIST through the NLIST website using login ID and password. 
Table 8 describes that 32 respondents' skills about OS (Operating System) is above average and 47 respondents' MS office related skills are excellent. The 46 Library professionals' mentioned that their skills about library automation software are excellent and most of the libraries of these respondents are already automated. While 9 respondents mentioned their level of RDBMS is excellent. The ICT skills levels of other skills are mentioned in Table 8.

\subsection{Information about status of library automation}

Table 9 describes that $40(51.9 \%)$ library professionals are working with the fully automated library system, while $14(18.2 \%)$ of respondents are functioning manually to provide library services, teaching support and planned to start library automation in the future. The study also investigated by whom the library automation process was/ will be carried out.

Information about staff involved in library automation process mentioned in Table 10. The libraries working manually to provide library services such as issue/return and other library services are $14(18.2 \%)$, the study also surveyed with their future plan about by whom library automation process would be carried out and presented in Table 10. It described that there are 4 respondents that could not respond due to the unavailability of library automation software, 20 respondents informed that library automation process done by themselves and 19 respondents do it with the help of outsource agency.

\subsection{Challenges to use technology}

Table 11 described challenges to use technology, most of respondents strongly agree because of lack of manpower, additional work/duties, and lack of IT Infrastructure.

\subsection{Attitude of library professionals towards ICT}

Attitude of library professionals towards ICT analyzed and presented in Table 12, majority of respondents strongly agree with Application of ICT proved beneficial to do library works quickly and Application of ICT is necessary to provide quality library services.

Table 13 mentioned that majority $53(68.8 \%)$ of respondents informed that library patrons approached library staff via phone calls, social media/WhatsApp chat during lockdown period.

\subsection{Methods used to guide users to access online resources}

Figure 2 exhibits methods used to access e-resources and guide users when the library was not accessible physically. The institute/library website is considered as a popular method to guide such as user guide available at website of Nirma University Technology Library https://technologylibrary.nirmauni.ac.in/resources/electronic-resources/ (Figure 3) and provided resources to users as $55(71.43 \%)$ respondents used this method. While $8(10.39 \%)$ LIS professionals adopted other methods such as sending eBooks and articles via email and provided links to resources via social media. 


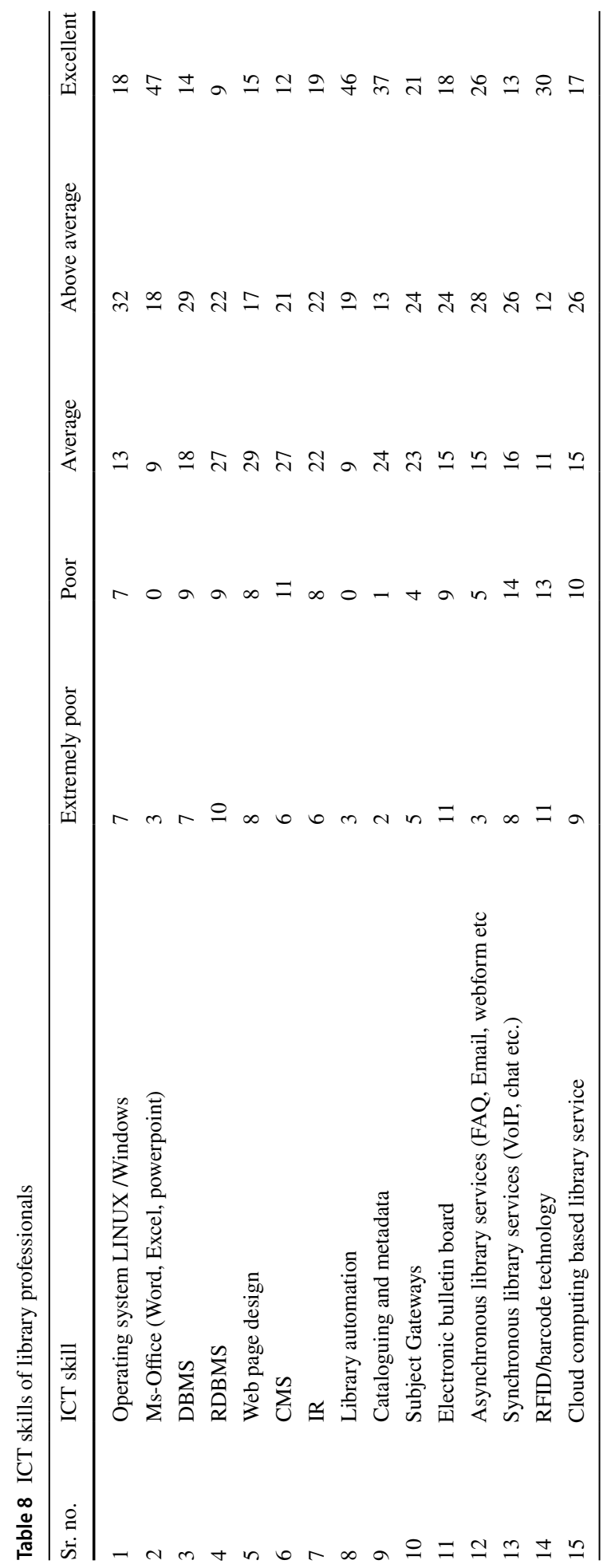


Table 9 Information about library automation

\begin{tabular}{llll}
\hline Status of library automation & & & \\
\hline PBF(planning to begin in the future) & Hybrid & Fully automated & Total \\
\hline $14(18.2 \%)$ & $23(29.9 \%)$ & $40(51.9 \%)$ & $77(100 \%)$ \\
\hline
\end{tabular}

Table 10 Information about staff involved in the library automation process

\begin{tabular}{lll}
\hline Sr. no. & Library automation done by & Respondents \\
\hline 1 & Self (Library professionals) & 20 \\
2 & Help of out source agency & 19 \\
3 & Self and institute IT staff & 14 \\
4 & Institute IT staff & 8 \\
5 & Help of outsource agency and self & 7 \\
6 & Help of outsource agency and institute IT staff & 4 \\
7 & Not known/undecided & 4 \\
8 & Help of outsource agency, self, institute it staff, & 1 \\
9 & and library staff & 77 \\
\hline
\end{tabular}

Table 11 Challenges to use Technology

\begin{tabular}{|c|c|c|c|c|c|c|}
\hline Sr. no. & Challenges & Strongly agree & Agree & Undecided & Disagree & $\begin{array}{l}\text { Strongly } \\
\text { disagree }\end{array}$ \\
\hline 1 & Lack of IT infrastructure & 23 & 27 & 10 & 11 & 6 \\
\hline 2 & Additional work/duties & 22 & 36 & 9 & 8 & 2 \\
\hline 3 & Lack of manpower & 20 & 43 & 6 & 7 & 1 \\
\hline 4 & $\begin{array}{l}\text { Lack of support from the higher } \\
\text { authority }\end{array}$ & 18 & 24 & 21 & 8 & 6 \\
\hline 5 & Lack of internet connectivity & 12 & 31 & 15 & 11 & 8 \\
\hline 6 & $\begin{array}{l}\text { Lack of ICT skills among LIS profes- } \\
\text { sionals }\end{array}$ & 11 & 36 & 12 & 13 & 5 \\
\hline 7 & Lack of motivation & 10 & 34 & 12 & 15 & 6 \\
\hline 8 & Unwillingness & 6 & 22 & 23 & 16 & 10 \\
\hline 9 & Technologies not required & 3 & 9 & 23 & 19 & 23 \\
\hline 10 & Not facing any challenge & 3 & 14 & 22 & 26 & 12 \\
\hline
\end{tabular}

\subsection{Level of Library Users' Satisfaction with only e-resources usage}

During the lockdown period, physical collection of most of the libraries was not accessible and the utilization of e-resources was the solution, it is also observed that e-resources usage increased significantly during this period. This study collected information about users' satisfaction with e-resource collection as all of the libraries subscribed to e-resources. As per Figure 4, $26 \%$ of LIS professionals informed that their user community is satisfied with e-resources as 


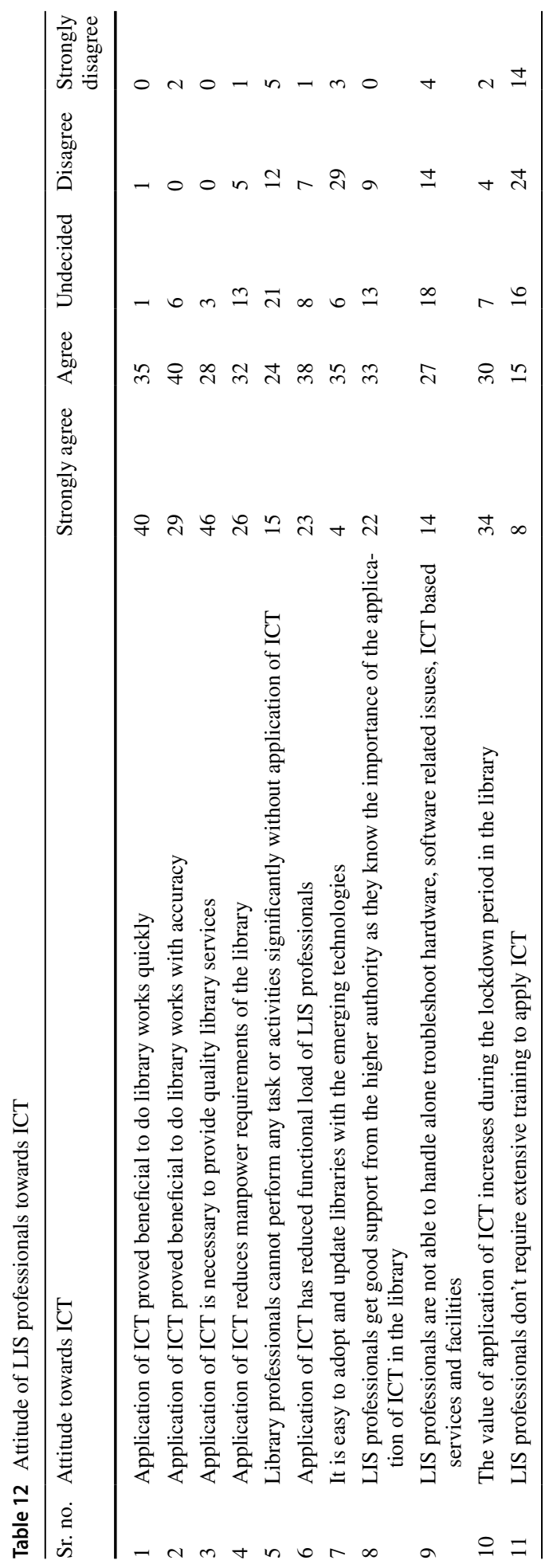


Table 13 Methods used by library patrons to approach library staff during lockdown

\begin{tabular}{llll}
\hline Sr. no. & Method & Respondents & Percentage \\
\hline 1 & Via phone calls & 53 & 68.8 \\
2 & Social media/whatsapp chat & 53 & 68.8 \\
3 & E-mail & 51 & 66.2 \\
\hline
\end{tabular}

Multiple options selected by respondents

they found quality e-resources and flexibility of use, $14 \%$ refused as they wanted to use the print collection of libraries, and $29 \%$ were unaware of the satisfaction level of users with e-resources.

\subsection{Nature of Problems faced by Users to access e-resources:}

Figure 5 exhibits that $36(46.75 \%)$ respondents considered lack of ICT skill of users is the hurdle to access e-resources, 29 (37.66\%) mentioned lack of internet/ slow connectivity is an issue and other problem factors regarding e-resource access are described as above.

\section{Recommendations}

In the COVID 19 situation, many libraries and Information centers provided ICT based library services to fulfill diverse needs of users, moreover cloud-based library services, remote login facility to use online resources without visiting libraries physically, Mobile Library App to access all online journals, databases, maintaining library website with

\section{Methods used to guide users to access online resources:}

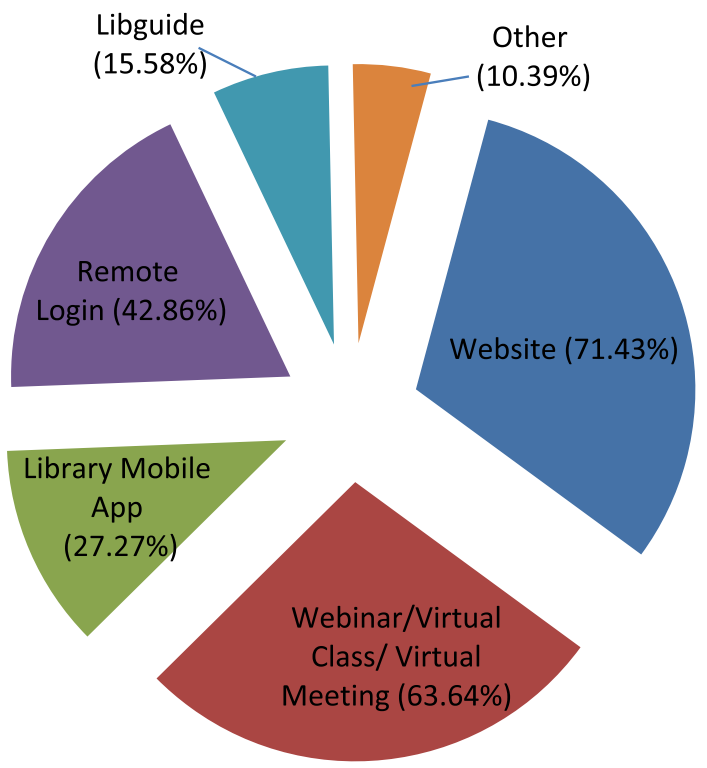

Via website

- Webinar/ Virtual class / Virtual Meeting

- Library Mobile App

Enabled Remote login facilities

- Via Libguide

Other

Fig. 2 Methods used to guide users to access online resources 


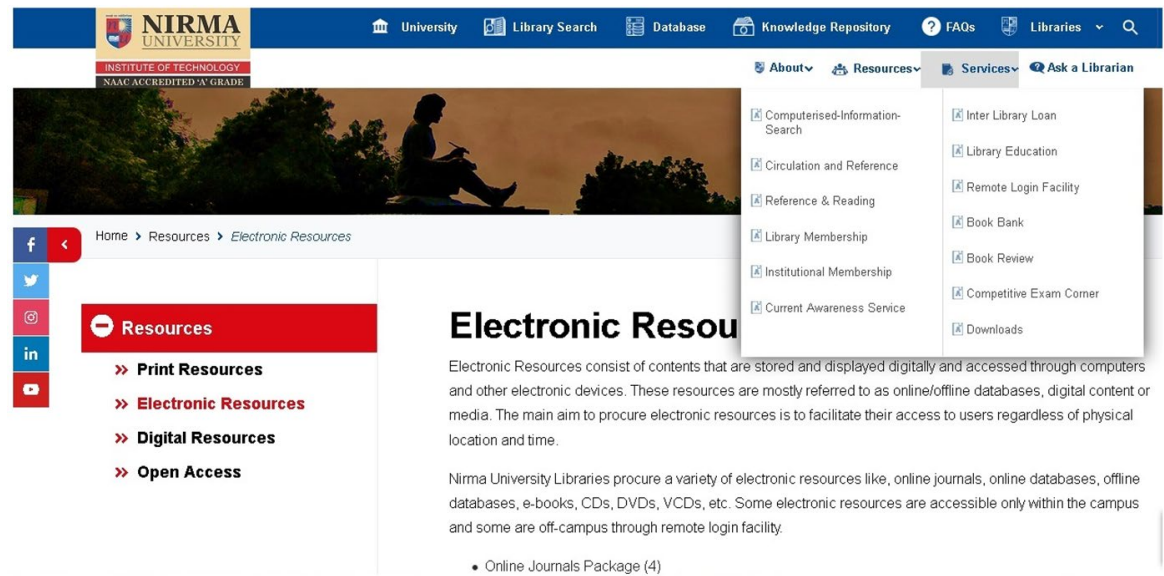

Fig. 3 Library Website of the Institute of Technology Nirma University. Source https://technologylibrary. nirmauni.ac.in/resources/electronic-resources/. (Source: https://technologylibrary.nirmauni.ac.in/resources/ electronic-resources/)

Fig. 4 Library Users' Satisfaction with only e-resources usage

\section{Library Users' Satisfaction with only e-resources usage}

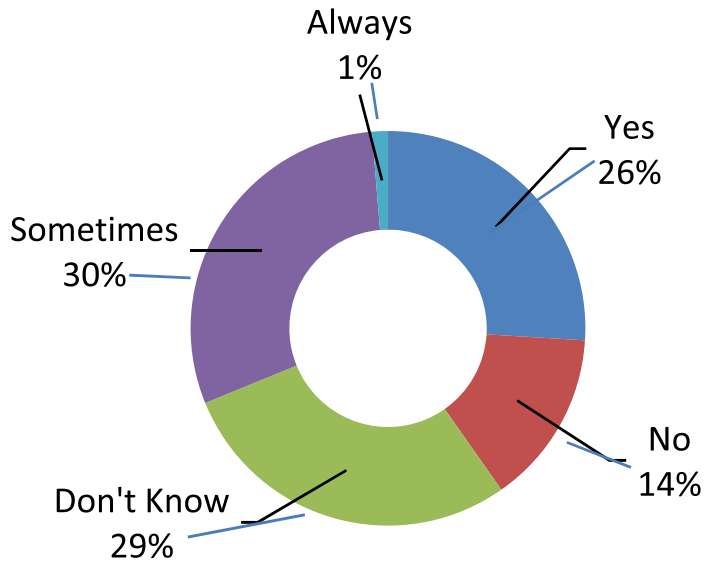

a comprehensive guide about how to access library resources, how to login to access e-resources, usage of mobile library app, etc. prove beneficial for users and increase utilization of resources, in this direction other recommendations are:

1. In the current COVID-19 pandemic situation, library and information professionals have to enhance their ICT skills in CMS, cloud computing, synchronous and asynchronous services to provide better library services and fulfill the requirements of library users. Library and Information professionals should participate in workshops, seminars, webinars, MOOCs, short term courses to update their ICT skills. 
36

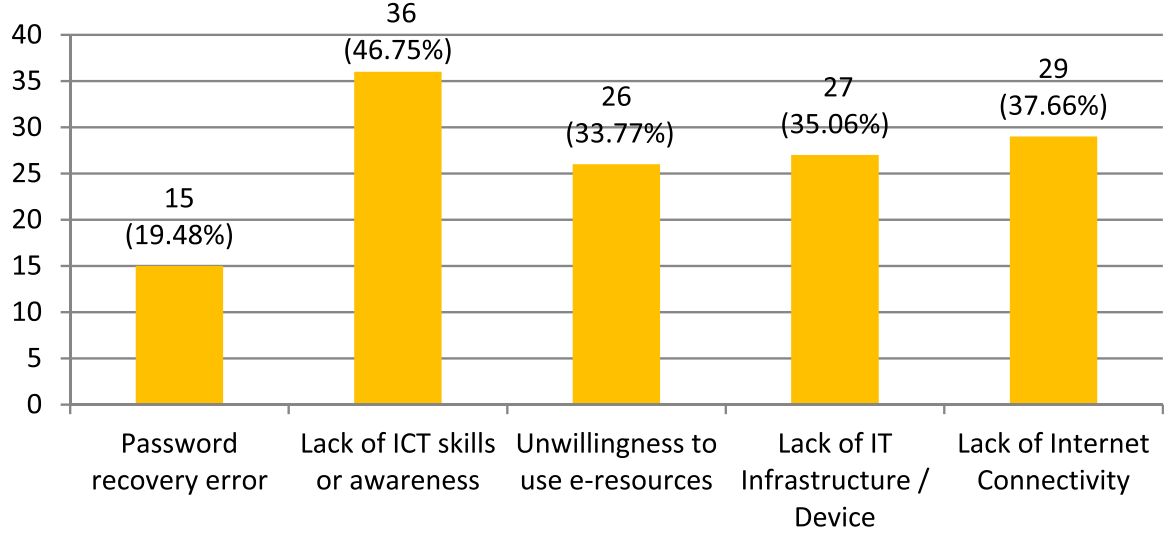

( ${ }^{*}$ multiple options selected by respondents)

Fig. 5 Nature of problems faced by users to access e-resources

2. The institutions should allocate funds at regular intervals for the training of LIS professionals and to modernize libraries with the latest technologies.

3. Library user is the key component of the system, know the Customer is the principle rule. The collection of feedback of users about resources and services is an important part; LIS professionals should know the level of satisfaction of users with e-resources and services.

4. The dearth of skilled manpower is also pointed out in the findings of the study. There is an urgent need of appointing skilled professionals in adequate proportion in the libraries.

5. Internet connectivity is the backbone of e-content access and training in the online learning environment. Hence it is recommended to improve the IT infrastructure of academic institutes as well.

6. Library professionals should emphasize upon the usage of online forums, social media, library mobile app, FAQ, online databases, Institutional Repository, Remote login, Online Exam paper archive, Library website, etc. to help users to access library resources and services beyond four walls of the library.

7. Library users also needed to enhance their ICT skills as per market innovation.

8. It is inevitable to create awareness and promote the usage of online and open access e-resources among users. 


\section{Conclusion}

The study surveyed ICT skills and attitudes of LIS professionals of Gujarat State, India, the study also discussed ICT challenges prevailing in the library service scenario during COVID 19. The study identified usage of library websites, and e-resources increased tremendously due to COVID 19 however, the challenges associated with utilization of e-resources such as lack of ICT skills, internet connectivity and IT infrastructure also highlighted. It is necessary to create more awareness among users about e-resources and LIS professionals should organize online training sessions to aware and guide them about accessing e-resources. The study described recommendations about skill development and focus on ICT to improve library and information services to serve the library community efficiently. 


\section{Appendix}

ICT Skills and Challenges of Technologies Usage by the LibraryProfessionals of the Gujarat State during the Lockdown Period: A Comprehensive Study

General Information

*Required

1. Email address *

2. Name of the College / University / Institute *

3. Kindly Select the Type of your Institute * Mark only one oval.

Autonomous / Self Finance

Government

Grant in aid

Central Government

4. Kindly Select Your Professional Designation * Mark only one oval.

Library / Technical Assistant

Library Professional

Assistant Librarian

Deputy Librarian

Librarian

Other:

5. Your basic Qualification (Mark in Higher) * Mark only one oval.

\section{B.A}

B.Com

B. Sc

M. A

M. Com

M. Sc

Other: 
6. Kindly select Your Professional Qualification * Tick all that apply.
B. L. I. Sc.

M. L. I. Sc.

M. Phil.

Ph. D.

\section{$\square$ NET / SLET}

7. Courses offered in your College / Institute * Tick all that apply.

$\square$ Under Graduate

$\square$ Post Graduate

$\square$ Diploma

M. Phil

$\square$ Ph. D

Other:

8. Year of College Establishment * Mark only one oval.
$\longrightarrow$ before 1950
$\longrightarrow 1951-1970$
$\longrightarrow 1971-1990$
$\longrightarrow 1991-2010$

$\longrightarrow$ After 2010

9. Library Working Hours (Daily) * Mark only one oval.
C 1 to 7
$\longrightarrow 1$ to 8
$\longrightarrow 1$ to 9
C More than 9 Hours

10. Library Budget (annually) * 
Mark only one oval.

Up to 10,000

10,001 to 20,000

$20,001-30,000$

$30,001-50,000$

Not Specific

Other:

11. Please Specify Total number of Library Patrons *

12. Approximate no. of users visiting library (physically/virtually Daily) * Mark only one oval.

Up to 100

101 to 200

201 to 400

401 to 500

More than 500

13. Library Working Hours (Daily) *

Mark only one oval.

1 to 7

1 to 8

1 to 9

More than 9 Hours

Library Resources and Services (No. of Books/ journals and E-resources)

14. Library Facilities (for patrons): *

Tick all that apply.

Library Building

Reading Room

Photocopying

Printing

Internet

Scanning 
Other:

15. Library and Information Services *

Tick all that apply.

$\square$ Circulation

$\square$ New Arrivals

$\square$ Reference Service Online database search

$\square$ Documents Delivery Services (DDS)

$\square$ Newspapers Clippings

$\square$ Online Database Search

CAS(Current Awareness

Service)

SDI (Selective Dissemination of Information)

ILL (Inter Library Loan)

Value added Services

Indexing and abstracting service

Other:

16. Total Number of the Library Staff * Mark only one oval.
$0-1$
2-5
5-10
more than 10

17. Kindly give information about vacant posts in the Library * 
18. Total number of Books *

Mark only one oval.

1 to 2,000

2,001 to 5,000

5,001 to 10,000

10,001 to 15,000

15,001 to 20,000

20,001 to 30,000

30,001 to 50,000

More than 50, 000

19. Total number of Print Journals, Periodicals, Magazines Subscribed annually (approximately) *

Mark only one oval.

1 to 20

21 to 30

30 to 50

more than 50

20. Does your Library provide e-Resources, If yes, kindly mention details of e-resources.

21. ICT skills of Library Professionals (Please Tick) *

Mark only one oval per row. 


$\begin{gathered}\text { Extremely Poor Average Above Excellent } \\ \text { Average }\end{gathered}$
Average

Operating System LINUX/ WINDOWS
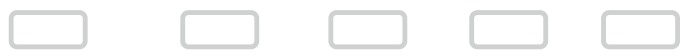

Ms-Office (Word, Excel, powerpoint)
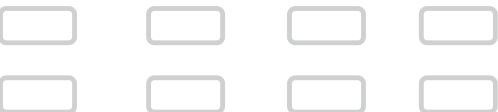

DBMS
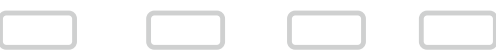

RDBMS

Web page design


CMS
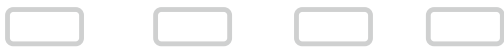

IR (Institute repository software)
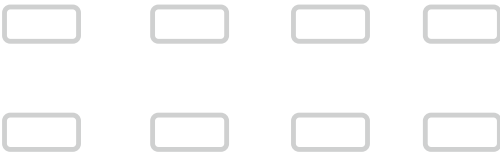

Library Automation

Cataloguing and Metadata
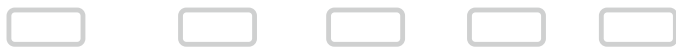

Subject Gateways
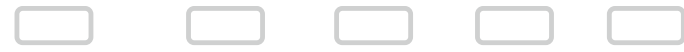

Electronic Bulletin Board


Asynchronous Library Services
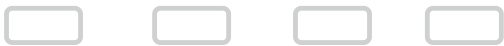

(FAQ,Email, webform etc.)

Synchronous library services (VoIP,Chat etc.)
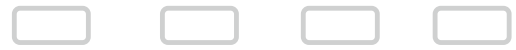
RFID/ Barcode Technology

Cloud Computing based Library Services

22. Information about Library Automation * Mark only one oval.

\section{Fully automated}

Hybrid

PBF (Planned to Begin in the Future)

23. Library Automation/Installation Process done by *

Tick all that apply.

Self (Library Professionals)

Help of Out Source Agency

Self and Institute IT staff

Institute IT staff

Help of Outsource Agency and Self

Help of Outsource Agency and Institute IT staff

Not Known/ Undecided

Help of Outsource Agency, Self, Institute IT staff, and Library Staff elf and

24. Have you received any training for ICT? *

Mark only one oval.

\section{Yes}

No

25. Challenges to use Technology *

Mark only one per raw

\begin{tabular}{|c|c|c|c|}
\hline $\begin{array}{c}\text { Strongly } \\
\text { Agree }\end{array}$ & Agree & Undecided & Disagree \\
\hline
\end{tabular}


Lack of manpower

Heavy workload

Additional work/ duties
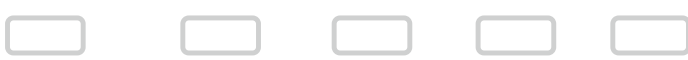

Financial barriers
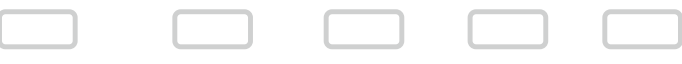

Lack of ICTskills among LIS
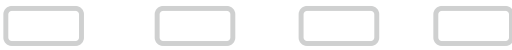

professionals

Lack of support fromthe higher authority

Lack of IT Infrastructure
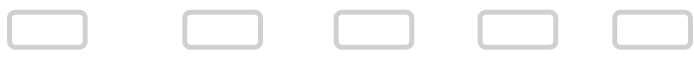

Lack of Internet Connectivity


Lack of Motivation
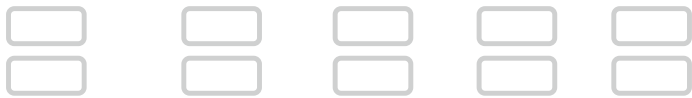

Technologies Not Required

Not Facing any challenge
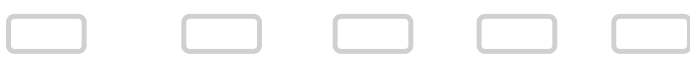

Unwillingness

26. Attitude of LIS Professionals towards ICT *

Mark only one oval per row.

$\begin{array}{cccc}\begin{array}{c}\text { Strongly } \\ \text { Agree }\end{array} & \text { Agree } & \text { Undecided Disagree } & \begin{array}{c}\text { Strongly } \\ \text { Disagree }\end{array}\end{array}$

Application of ICT provedbeneficial to do library works with speed.
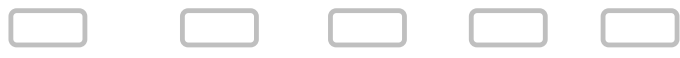

Application of ICT is necessary to provide quality libraryservices.


Application of ICT reduces manpower requirements of the library


Library professionalscannot perform any task or activities significantly without application of ICT

Application of ICT has reduced functional load of LIS professionals

It is easy to adopt and update libraries with the emerging technologies

LIS professionalsget good support fromthe higher authority as they 
know the importance of the application of ICT in the Library

LIS professionalsare able to handle alone troubleshoot hardware, software related issues, ICT based services and facilities.

The value ofapplication of ICT in thelibrary increases during the lockdown period.

LIS professionalsdon't require extensive training to apply ICT.
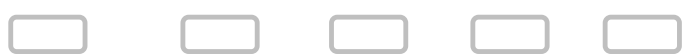

Application of ICT proved beneficial to do library work with accuracy.

27. Have you received demands from the library users or you offer library services during lock down time or when library not physically accessible? *

Mark only one oval.

Yes

No

28. How users approach you during lock down or when library not physically accessible? $*$

Tick all that apply.

Via phone calls

Social Media / Whatsapp Chat

E-mail

Other:

29. How do you guide users during lockdown to access resources? *

Tick all that apply.

Via website 


\section{Webinar/ Virtual class / Virtual Meeting}

Library Mobile App

Enabled Remote login facilities

Via Libguide

Other:

30. Does Library users satisfy with only e-resources? * Mark only one oval.

Yes

No

Don't Know

Sometimes

Always

31. Do you think library users are well trained to use Library e-resources? * Mark only one oval.

\section{Yes}

No

32. If no, which kind of problem they face?

Tick all that apply.

Password recovery error

Lack of ICT skills or awareness

Unwillingness to use e-resources

Lack of IT Infrastructure / Device

Lack of Internet Connectivity

Other:

33. Kindly describe / share your suggestions / recommendations to improve library management and services in present Covid-19 scenario. 


\section{References}

Ahmad, S., Lone, J.A., Basharat, M.: Perception of using ICT in libraries: a survey of library professionals working in Government Degree Colleges of Kashmir (J\&K)-India. Pearl J. Libr. Inf. Sci. 14, 65-70 (2020). https://doi.org/10.14429/djlit.35.4.8844

Babu, B.R., Vinayagamoorthy, P., Gopalakrishnan, S.: ICT skills among librarians in engineering educational institutions in Tamil Nadu. DESIDOC Bull. Inf. Technol. 27(6), 55-64 (2007). https://doi.org/ 10.14429/djlit.27.6.145

Basahuwa, C.B., Unegbu, V.E., Babalola, Y.T.: ICT skills and job performance of librarians in Public Universities in North-Central Nigeria. J. Sci. Technol. Educ. 8(1), 154-166 (2020)

Buarki, H., Hepworth, M., Murray, I.: ICT skills and employability needs at the LIS Programme Kuwait: a literature review. New Libr. World 112(11/12), 449-512 (2011)

Gurikar, R., Mukherjee, B.: Information technology usage scenario in academic libraries of higher education in Chhattisgarh: challenges and opportunities. DESIDOC J. Libr. Inf. Technol. 35, 273-280 (2015). https://doi.org/10.14429/djlit.35.4.8844

Jalal, S.K.: Emerging roles of librarians in academic libraries: a great leap forward. Libr. Herald 57, 183194 (2019). https://doi.org/10.5958/0976-2469.2019.00010.1

Jankowska, M.A.: Identifying university professors' information needs in the challenging environment of information and communication technologies. J. Acad. Libr. 30, 51-66 (2004). https://doi.org/10. 1016/j.jal.2003.11.007

Kaur, R., Sharma, A.K.: 21st Century library professionals in dynamic role in digital era. Library Progress Int. 38, 129-139 (2018). https://doi.org/10.5958/2320-317X.2018.00013.2

Mandal, S., Dasgupta, S.: Changing role of academic librarians in 21st century: a literature review. Pearl J. Libr. Inf. Sci. 13(1), 35-44 (2019)

Oyedokun, T.T., Oyewumi, F.A., Akanbi, M.L., Laaro, D.M.: Assessment of ICT competencies of library staff in selected universities in Kwara state, Nigeria. Libr. Philos. Prac. e J. 1797, 1-36 (2018)

Palczyńska, M., Rynko, M.: ICT skills measurement in social surveys: Can we trust self-reports? Qual Quant (2020). https://doi.org/10.1007/s11135-020-01031-4

Raju, J.: Knowledge and skills for the digital era academic library. J. Acad. Libr. 40, 163-170 (2014). https://doi.org/10.1016/j.acalib.2014.02.007

Seena, S.T., Pillai, K.G., S. : A study of ICT skills among library professionals in the Kerala University Library System. Ann. Lib. Inf. Stud. ALIS 61, 132-214 (2014)

Sen, B.K.: Ranganathan's five laws. Ann. Libr. Inform. Stud. 54, 87-90 (2008)

Thanuskodi, S.: Information literacy: accessibility and skills among Indian LIS professionals. Libr. Prog. Int. 39, 13-30 (2019). https://doi.org/10.5958/2320-317X.2019.00002.3

Publisher's Note Springer Nature remains neutral with regard to jurisdictional claims in published maps and institutional affiliations. 